\title{
The regulation of tourism settlements in the Portuguese territory: trade-offs and inefficiencies
}

\author{
J.-M. Carvalho \\ Faculdade de Arquitectura, Universidade de Lisboa, Portugal
}

\begin{abstract}
The regulation of the tourism settlements in the Portuguese territory has focused on the specification of the operation requirements that tourism ventures have to comply with, under the major aim of stimulating the tourism investment wherever the State sees tourism as the effective or potential regional economic base. The impacts of the tourism settlements on the environment and on social cohesion, items to be dealt with under the sustainability banner, are regulated through non-specific tourism spatial laws and norms. The consensual concern with sustainability highlights the gap between an integrated approach to tourism regulation and the generalist one that has prevailed. The regulation aim of stimulating and protecting the tourism investments has furthermore been based upon the assumption of economic growth. The regulation does not, therefore, deal with situations where the reversal or deep reconversion of half-developed settlements become the main concern due to insolvency of the developer and disinterest of the developers' community. An integrated approach of the tourism settlements regulation should be able to allow for a preventive management of the reversal costs of the permitted settlement.

Keywords: regulation, resort development, sustainability, trade-offs businesscommunity.
\end{abstract}

\section{Introduction}

Portugal is a consolidated tourism destination. Its temperate climate, long seafronts, historical features and safe social fabric have made it attractive for modern tourism since the early 1960s. This attractiveness partially derives from a weak historical industrialisation which has not spoiled the landscape but has never been 
a wealth provider as well. Thus the less developed the territory, the more pristine and the more important the tourism as the regional economic base.

Tourism in Portugal has accordingly been fostered as an economic activity through public incentives and regulatory privileges for more than 50 years. Tourism destination requirements and market demands have changed as well as the rationale for tourism as a regional economic base has evolved from no environmental impact concerned to the sustainability discourse.

The main tourism areas - coastal zones - have been occupied by tourism developments, which were mainly hotels when the occupation started and mostly real estate units in the further stages.

The former settlements have not met location restrictions and have occupied sites no longer available on the grounds of conservation restrictions, such as seafront on the first line. The urban design and the buildings of those developments meet, on the other hand, unavoidable obsolescence.

The latter settlements had to invest a lot in creating attractive features - such as golf courses - to make their sites competitive and autonomous as leisure venues. In some cases however the unsuitability of the site overcomes the installed features and the businesses fail.

The economic crisis in Europe where Portugal's tourists mostly come from, has originated an unbalanced market for non-hotel resort tourism with reduced demand and a very large supply. This brings accrued risks for the private tourism businesses but also for the local and regional communities as the latter count on the success of the former [1], having accepted trade-offs between environment and family incomes.

\section{Research question and methodology}

The main research item is the suitability of tourism regulations. The regulations have been launched decades ago to foster tourism as an economic activity. To go on achieving this initial purpose, namely given the importance of tourism for weak economies, tourism regulation disregards the societal variables that might deter tourism investment or operation. Whenever the social benefits of the tourism business are mitigated by economic crisis, the trade-offs that supported the tourism regulation choices are questioned in the name of those disregarded societal variables. Why have regulations not included an integrated approach to the tourism activity? What should this one be like?

The methodology to address these questions needs, as a first step, to confine the relevant notion of tourism activity. In this paper it will be confined to the settlements we normally call tourism resorts; we define them in a special section.

The next step concerns regulation itself. Law is the type of regulation taken into account and territorial occupation is the scope the paper focuses on.

A third step deals with the societal variables that tourism regulation historically tends to leave behind. Those variables are presently aggregated in the sustainability approach and so this paper takes sustainability as a relevant approach to an integrated regulation. 
The experimental step of the methodology explores, in a chronological approach, the connection between the tourism regulation and the social efficiency of the resorts on the perspective of sustainability.

Portugal is the reference for all the concrete mentions in the paper. Though this limits the scope of the conclusions it nevertheless refers them to a paradigm, since, from the middle of the $20^{\text {th }}$ Century, Portugal has been one of the relevant European tourism destinations.

\section{Tourism resorts as case studies}

Tourism resorts are settlements that have a significant territorial meaning, due to size and physical connections with local space networks. However, the designation covers different types of settlements that derive from their genesis.

The historical resort is an organic settlement that grew based on the leisure abilities of a pre-existent urban fabric, be it as a fisheries village or a mediaeval wall-enclosed town. The initial growth of these organic settlements, up to the point of becoming a tourism resort, did not meet regulatory restrains in the sense that every property could be freely added to the ones previously allocated to tourism purposes. These tourism settlements, which identify themselves with an old geographical place-name and are nowadays merely subjected to urban planning regulation, are not the subject of this paper.

Two other types of tourism resorts can nevertheless be found that are of concern for our purposes. They are distinct from the previous case in that they have a sole first instance developer for each resort and were developed ex novo. This category comprehends two types - the resort developed in one property (or set of properties brought together for the purpose) and the multi-resort development in one huge property, which can be illustrated by the three well known Portuguese resorts of Vale do Lobo (450 hectares, 1962), Vilamoura (1,600 hectares, 1966) and Quinta do Lago (645 hectares, 1975), all of them in the Algarve.

The one-property resort development (OPRD) is the most recent resort type in Portugal and includes a very important real estate component. It deserves the designation "resort" (which is not a Portuguese word) in the Portuguese law. The resorts of this type are the central concern of the present paper.

The multi-resort development (which is a rare type of resort) includes resorts that have been installed along the second half of the $20^{\text {th }}$ Century up to the present, having therefore met different market demands and regulatory restrains along time. The resorts within multi-development resorts are also the concern of this paper.

OPRD and multi-resort developments have a common feature, though the similarities are more apparent than real. The common feature is their dependence, from the start, on an urban plan; the difference is that for the recent OPRD the plan is a public top-down imposition and for the multi-development resort it was, at the time, a bottom-up option in order to guarantee the urbanization and construction rights for the future.

The top down urban plan imposed upon the recent OPRD ensures that the local community has a share of the business margin of the developer, even if not 
expressed in this crude way. The multi-resort development obtained its urban plans rights in an epoch where urban planning was a competence of central government and this one wanted to stimulate all tourism investments.

\section{Tourism regulation}

\subsection{Regulation}

Regulation assumes the market is malfunctioning in terms of social efficiency, for the purposes of this paper meaning the generation of negative externalities by private economic agents or their unbalanced use of public goods.

The aims and scope of regulation vary along time according to what civilization starts assigning more value and which was not previously so much valued. Negative externalities that once were accepted are now internalized via regulatory norms. The scope of the concept of public good itself is extended to concepts such as "social capital". Regulation can fail its aim by un-thoroughly ignoring possible negative externalities or un-creatively restricting the definition of public goods.

Market regulation may assume the form of market related mechanisms (such as the $\mathrm{CO}^{2}$ emission rights) or the form of laws and norms to directly abide for. Regulation concerning the occupation of the territory normally takes the second form. This does not however mean that these law norms may ignore the functioning of the relevant markets or even that they have to give up a non-fiscal caption of a share of the business margins. This is the domain where regulation meets governance.

The framework for good governance should be provided by regulation though feedbacks are expected to exist. In the domain of territorial occupation we may say that planning obligations derive from regulation, though their execution is a matter of governance; the same is valid, though within a much volatile and argued context, for planning gains.

For the purpose of this paper regulation is therefore the set of norms private economic agents have to abide for and that specifically concern their business domain and that should be oriented towards the preventive management of negative externalities and of public goods, besides promoting downstream good governance.

\subsection{Tourism law}

\subsubsection{In the beginning}

The Portuguese law on tourism was launched having as sole concern the architecture of the tourism spaces, at the time mostly hotels. This matched the strategic aim of qualifying the Portuguese tourism within the Iberian supply.

Besides, the launching of a tourism venture required a declaration issued by the Tourism Department stating the "tourism utility" of the venture, which allowed for relevant fiscal benefits for the developer, as another form of investment stimulus. 
Urban planning was not generally a public restriction for tourism at this stage. The large resorts launched in the 1960s did not comply with previously existing urban plans as these did not exist. Where master-plans were required for private management purposes, developers agreed with the public authorities to convert them into fully legal urban plans, so that the corresponding construction rights and urban design features would be guaranteed in the long term. Such was the case of Vilamoura which internet site presents it as the largest private tourism multi-resort development in Europe.

It was mostly from 1974 onwards that public urban planning became common in Portugal. This means that prior to 1974 tourism ventures prevailed over informal conservation concerns, though they might be present in the developer's motu proprio strategy.

The inexistence of public urban plans allowed for a much sought after feature which was the sale of lots of land for secondary homes in tourism destinations, i.e. a private urban allotment scheme would be permitted and land could be sold as urban land which was previously rural.

\subsubsection{Land development restrictions}

In 1991 urban allotments outside the urban perimeter became interdicted. This was a major change that prevented developers from further on developing non-urban land for secondary homes.

The interdiction depended, however on the delimitation of the urban perimeters which was the task of the municipal plans. These, legally created in 1982, only had enforcing norms mostly after 1993. In between, urban permits submitted prior to 1991 went ahead.

\subsubsection{The update of the tourism law}

In 1997 a new tourism law was published to take into account major urban planning law and market changes. Most relevant among the latter was the role of tourism real estate in the tourism business. Its importance in Spain made the Portuguese developers lobby for similar chances since pure real estate land development had been severely curtailed by the enforcement of the 1991 law.

The 1997 law assumed that tourism permits could address the tourism business purpose of combining pure hospitality items with the sale of second homes. For this purpose, the 1997 law introduced the concept of tourism complex ("conjunto turístico", later renamed as "resort" - a non-Portuguese word - in the 2008 tourism law), as a large operation that could include real estate units. These tourism ventures had to submit a master-plan to both tourism and municipal authorities, which had however to comply with the existing municipal plan.

\subsubsection{The consolidation of the urban planning system and the tourism law}

In 1999, urban planning and permit laws underwent a major change. The system became globally stricter on territory transformation for private development with a very relevant and argued sole exception - urban allotments outside the urban perimeters became again possible for the tourism complexes ("conjuntos turísticos"). 
The new legal system also added the explicit possibility of association between municipal authorities and private developers for urban operations, such as land development for tourism resorts. The execution of the possibility normally came with an urban plan, which required the formal initiative of the municipal authority. This framework originated a new bargaining period between tourism developers and municipal authorities. The process often ended in a deed associated to a detail plan which included the spatial features convenient to the private developer's business, but through which the latter would offer the municipality an agreed benefit package which fits the planning gains concept.

In 2002, as the pipeline of permits submitted under the 1997 tourism law was coming to an end or awaiting a change in the tourism law to make it compatible with the 1999 system of territorial management, the tourism law was effectively changed. Urban allotments for secondary homes became allowed outside urban perimeters and in tourism destinations (defined as such in municipal plans) if under a tourism permit. This had, however, strings attached, as the developers had to install upmarket hospitality premises, large animation anchors (golf course was the most common choice) and - whenever detail plans were imposed to support the business - were led to pay a benefit package to the municipality.

Developers compensated such adverse features through the size of the development, diluting in a large land development the risk of hospitality premises and animation anchors and the sunk costs of the benefits the municipality had become entitled to receive. A lot of new resorts were launched.

\subsubsection{The present tourism law as it was in 2008 and 2009}

In 2008, a new tourism law was issued. The regulation went on focusing in the traditional concern with the quality of the developed space and in the more recent concerns of property rights and management in resorts with one developer but several real estate owners ("plural property" as the law had it) [2].

The law reduced the property rights of end-users and real estate investors and enhanced those of the managing entity of the resort, assigning the latter the possibility of imposing costs of property maintenance and giving it the leadership on the subject of shared management costs.

The unstated aim of the law might have brought into the hospitality sphere the homes that had been conceived as second homes real estate. It did however come in a period of huge supply and retracted demand, further hardening sales difficulties and the financial problem of the developers and the funding banks. This was perhaps the reason why the law was revised in 2009, to alleviate the burden of condominium charges upholding on properties for sale.

The effort to bring together into hospitality what were previously real estate units is also evidenced by the obligation of including every unit to sell (lots or built units) in a horizontal property master-deed, prior to any sale being possible. This meant that no urban allotment included in the tourism venture would now be dispensed from tourism condominium obligations. 


\subsubsection{The 2014 amendment to the present law}

The 2008/9 law was revised in the beginning of 2014. The main changes cover the items of the obligation of building hotels in the resorts and of the inclusion of all the villas in the horizontal property master-deed of the resort.

As for the first item the 2014 amendment allows for very small hotels to fulfil the hotel installation obligation and further allows for apartments to be installed in the remaining (i.e. non-hotel) part of previously hotel buildings.

As for the second item - the effort of eliminating pure real estate from urbanization operations permitted as tourism resorts - the amendment deals with existing urban lots with villas (built in between the lot purchase and 2008) through integrating them into the resort as a special kind of local hospitality premise if their owners refuse to be included in a sub-condominium for villas.

The tourism law of 2008 and its last amendments in 2014 may be taken as showing a later day conscience of the regulation void that stimulated huge land developments in the name of tourism and of its intrinsic shortcomings, namely in the oversupply of hotel rooms (31 new hotels with 2,635 rooms expected for 2013 and 25 additional ones for 2014 , in as small a country as Portugal).

\section{Sustainability}

\subsection{Approach to sustainability}

Sustainability is the answer to an ingrained human rationale that runs as "if you don't want to have problems in a future to which either you or those of your concern may end up belonging, spend no more than the income of your capital and leave the latter as intact as possible". The argument turns to what indeed is capital and what is income. The concept of capital has evolved from its financial scope to a much more enlarged one that has abridged environmental resources of several kinds and has lately comprehended social capital resources.

Giving the notion of sustainability an operational character, which includes its targeting a specific subject, is however a demanding task. Hereafter we will respond to this task by using a European Union (EU) work on the sustainability of tourism destinations [3].

The reference we use doesn't forego the importance of the economic aspects of sustainability. For settled destinations, in which tourism is an acknowledged economic base, sustainability has however other priorities, like the high marginal social cost of new tourism occupations or the criteria for the upgrade of existing ones. The sustainability approach is, on the other hand, different for tourism destinations in a take-off stage (though rare in Europe), since it is very high the social value of pristine tourism zones, coastal ones specially, with a weak human occupation.

We should at last mention the positive character of the sustainability approach, since sustainability aims to be at the core of the objective-function of the investment decision. It goes beyond the identification, analysis and mitigation of 
impacts that are the subject of environmental impact analysis, an ex ante ancillary investment evaluation that worked as an environmental orientation to previously settled investment decisions.

\subsection{Tourism sustainability}

The EU study [3] considers 4 basic categories for the analysis of the tourism destination sustainability, which are Destination Management, Economic Value, Societal and Cultural Impact and Environmental Impact.

The Destination Management category refers to the measurement of items that represent the global stance of the destination towards sustainability. Once chosen the indicators, their values have a marketing role besides their intrinsic role for sustainability. For a large OPRD they may be part of the business strategy.

The Economic Value category refers to value added measured through indicators that have a positive correlation with economic growth, such as occupancy rates, per capita expenditure by tourists, average stay, average price per room, employment and weight of local supplies to tourism units; health and safety non-hazards are included by the study in this category. Most of these indicators seem to have in view hotel resorts more than resorts with a great incidence of residential tourism, which is an important feature of OPRD.

The Societal and Cultural Impact category refers to the assimilation of tourism by the endogenous local community, measured by the relative weight of the former on the latter, the acceptance the local inhabitants may show of the tourists' presence, the regional mores shaken by alien ones and the integration of local historic and cultural assets into the global tourism business. All this may be an external concern for large OPRD and for multi-resort developments that aim at leisure autonomy from the regional context.

The Environmental Impact category refers to air pollution, garbage and sewage output, energy efficiency, biodiversity and landscape conservation, illumination and noise nuisance, water and beach quality management. Most of the indicators are quantified proxies (e.g. air pollution is partially dealt through the weight of soft mobility in the local transports system). The OPRD resort type addresses some of these issues through the acquisition of acknowledged building certifications such as LEED or BREEAM and through environmental certification for specific items, such as golf courses.

The overall sustainability analysis that this system of indicators provides might be seen as falling into a traditional approach, both for tourism as pure hospitality and for successful businesses. The territorial importance of residential tourism and the risk of failure for tourism business ventures launched within a context of hard competition and economic crisis make this system incomplete.

The EU system of issues and indicators (without discussing the accuracy of the proxies) leaves aside two important sustainability subjects - the social opportunity cost of tourism development (i.e. the value of no-development) and the reversion costs in case of business failure, which tend to be heavy [4]. 


\section{Regulation and sustainability in tourism resorts}

\subsection{The sustainability criteria in tourism regulation}

The positive character of the sustainability approach reveals whenever some of the above issues and indicators meet the marketing aims of the resort developers such is the case of environmental certifications. In these cases, no regulation seems therefore to be needed, besides the permit requirements.

There are other issues in the same system that may also be a tourism developer's concern from the start, e.g. mitigation of noise or illumination nuisances in large OPRD as a sine qua non condition for client comfort. Again, no specific regulation enforcement seems to be necessary beyond the client comfort requirements.

Other additional issues in the EU system would allow for the rating of resorts according to the spatial allocation of their operating costs (the more local, the better). In this case sustainability regulation would probably be welcome in the form of incentives, but its meaning would strongly depend on the volume of the operating costs. Large OPRD with a major component of residential tourism have small per square metre operating costs. Most recent large resorts make anyway a point of emphasising their regional procurement.

Furthermore, it is hard to accept that the installation of tourism ventures in Europe might rest on the depletion of common resources (e.g. beach water quality) by not complying with the available technology for avoiding physical externalities or hazards. The EU system of indicators seems therefore most useful to overcome the sustainability obsolescence of ancient tourism destinations, namely those that identify themselves with an old place-name. These cases are not however the concern of our approach, which focuses on OPRD and multi-resort developments.

Both tend to meet sustainability criteria in design and operation as a marketing device and have been thoroughly analysed by the public authorities for the issuance of the urban permits that support them. They have also - in the Portuguese case and as part of the urban permit bargaining - provided the local authorities with a package of planning gains that may be seen as fulfilling a financial sustainability role towards de local community.

The permit rationale and the associated bargaining procedures show that the community has some reservations concerning land development allowing it only if is thought to be compensatory. Whenever it is undoubtedly thought so, special permit procedures may even exist. The Portuguese State (as the Spanish one) has created a special permit regime for the largest investments, though not only for tourism investments. This framework points to an implicit trade-off which equates the value of no-development with all the benefits of the development if completed. The issue of development completion is brought to the forefront of OPRD sustainability.

The present sustainability approach, the permit obligations and the analysis of environmental impacts, mostly target the tourism operation issues as a hospitality business. The regulation maxima for resort developments are defined in number of beds, thus conforming to the hospitality perspective. The investment issues 
for installation are addressed by the permits, targeting the suitability of location for tourism ventures, the quality of produced space and the infrastructure requirements, plus the promised planning gains for the local authority.

The latter may however, since those promised benefits depend upon the financial health of the developer, end up sharing the business risk. The final balance between the value of no-development and the unfulfilled benefits promise might if known in advance, have oriented the authorities' decision towards the nodevelopment option (partially or totally).

This is a sustainability outcome, since the irreversibility of land developments is extremely expensive and would have to be financially supported by the community if developers filed for bankruptcy (which is the reason for the noncompletion of the scheme).

Such an outcome derives from the non-integrated approach of tourism regulation which is itself a consequence of the conceptual gap between what tourism resort development means for the tourism authorities and what it means for the developers. The gap concerns the role of residential tourism in resort development as a form of real estate business. It may be intentionally accepted even if not acknowledged by the tourism authorities as part of a fostering policy that is not however explicitly addressed. The non-integrated approach of the regulation consists on the separation of tourism regulation from land development regulation instead of regulating both businesses into one under the title of tourism regulation.

\subsection{Tourism regulation, sustainability and the developers' business strategies}

Our view is that the land development business is the key to understanding the tourism resort development business and through it finding the adequate sustainability regulation. The sustainability trade-off that regulation should meet is therefore the development benefits versus non-developed land value. Development benefits are the concern of the regulation.

OPRD have to meet requirements on the provision of hospitality premises and animation anchors (e.g. golf courses or marinas). Otherwise, the land development business will not be allowed. This is one of the ways the community has to be compensated from the loss of pristine land in coastal areas. It is also the core of tourism as hospitality, where the ability to create employment and enhance local economic opportunities resides.

Residential tourism is a real estate business that benefits from the presence of hospitality premises and animation anchors. The operating risks of the residential tourism component are very small and the expected margin on land is very high. The business rationale therefore points to the maximization of the developed land area subject to the restrictions of location suitability and of regulation.

The capital risk of the residential tourism business - the best available substitute for the urban allotments for secondary homes business when this becomes legally impossible - has however proved to be much higher than expected.

The initial investment is huge and break-even rests on the assumption of quick sales (always for the upper market), not compatible with economic downturns. 
The outcome was the developers search for large land development opportunities in compliance with the obligation to install hotel and leisure anchors and the halting both of ongoing developments due to financial shortcomings and of new developments due to severe restrictions to the land development business. The expectation of high business margins on land development led the developers to negotiate with municipalities within urban plans, since the opportunity depended on the latter. Table 1 illustrates this point of view with a sample including some major Portuguese resort developments.

Table 1: Resort features by regulation period.

\begin{tabular}{|c|c|c|c|c|c|c|c|}
\hline Name & $\begin{array}{c}\text { Launching } \\
\text { year }\end{array}$ & $\begin{array}{l}\text { Area } \\
\text { hect. }\end{array}$ & $\begin{array}{c}\text { Villa } \\
\text { lots } \\
n\end{array}$ & $\begin{array}{c}\text { Built } \\
\text { villas } \\
n\end{array}$ & $\begin{array}{c}\text { Town } \\
\text { houses } \\
n\end{array}$ & Apartments & $\begin{array}{c}\text { Hotel } \\
\text { rooms } \\
n\end{array}$ \\
\hline Vale do Lobo & Prior to & 450 & $\mathrm{x}$ & 60 & 102 & 145 & 154 \\
\hline Vilamoura & 1991 & 1650 & $\mathrm{x}$ & $\mathrm{x}$ & $\mathrm{x}$ & $\mathrm{x}$ & 1305 \\
\hline Q. do Lago & & 645 & 620 & & 208 & 278 & 301 \\
\hline Soltróia & & 137 & 1143 & & & & \\
\hline Praia d'El Rey & & 170 & 302 & & 955 & & 177 \\
\hline Bom Sucesso & & 164 & 293 & & 308 & & 120 \\
\hline Q. de Óbidos & 2002 to & 58 & 79 & & & 84 & \\
\hline Royal Óbidos & $2008 / 09$ & 134 & 131 & & & 456 & 40 \\
\hline Tróia Resort & & 440 & 595 & & 1276 & & 300 \\
\hline P. Eco-resort & & 100 & & 82 & 43 & 34 & 150 \\
\hline F. d'El Rey* & 2009 to & 230 & & 78 & 205 & 192 & $\mathrm{x}$ \\
\hline T. UNOP 7 * & the present & 100 & $\mathrm{n} / \mathrm{a}$ & $\mathrm{n} / \mathrm{a}$ & $\mathrm{n} / \mathrm{a}$ & $\mathrm{n} / \mathrm{a}$ & 150 \\
\hline T. UNOP $8 *$ & & 99 & $\mathrm{n} / \mathrm{a}$ & $\mathrm{n} / \mathrm{a}$ & $\mathrm{n} / \mathrm{a}$ & $\mathrm{n} / \mathrm{a}$ & 166 \\
\hline
\end{tabular}

$\mathrm{x}=$ existing features $\mathrm{n} /$ quant.

* = non-achieved.

The darker grey highlights the properties for sale that correspond to the land development business and the lighter grey the pure hospitality component. Townhouses and apartments are in-between, the former closer to the land development business and the latter closer to hospitality. The resort development activity was irrelevant in the periods 1991-1997 (interdiction of the land development business outside urban perimeters) and 1997-2002 (residential tourism was introduced in 1997 and the land development business became possible within resorts in 1999, though the 1997 law was only revised for the 
purpose in 2002). Since the 2008 law severely restricted the land development business, the villas no longer appear as a settled intention for future developments.

The development of tourism resorts in the period after 2002 was centred in the OPRD type and led by real estate teams. Real estate or building companies entered the business with an ad hoc tourism brand of their own. The exception seems to be hotel groups that adopted a specific stance towards resort development and even separated from their initial real estate partners.

\section{Conclusion}

Regulation did not, in the Portuguese case, acknowledge the shift that tourism resort development underwent from hospitality to real estate. This had the consequence of having sustainability sought through the hospitality component, but leaving unregulated the real estate component that corresponds to a very large area. The assumption had been that urban planning laws would be enough to control land development even if tourism investment was being stimulated and protected. Tourism real estate may have been dealt with as a lateral subject and benefited from a regulation void, either created on purpose or not. This had the effect of stimulating the land development size of tourism ventures which was central to the developers' strategy in the period 2002-2008.

A specific sustainability regulation to address the issue of the lack of local social benefits derived from residential tourism should be based upon an analysis of the OPRD business under the lens of the public authorities' aims. The definition of development stages based on that analysis could serve the purpose; only upon the completion of each stage and the corresponding delivery of the benefits package to the local communities would the next stages be permitted.

The alleviation of the burden of OPRD permit obligations as a solution to financial real estate problems is said to be taken as unfair by pure tourism hospitality resort developers.

\section{References}

[1] Michaud, J. (ed.), Tourismes: chance pour l'Économie, risque pour les Sociétés? PUF, Paris, 1992

[2] Oliveira, F.P.; Abreu, A., Instalação de empreendimentos turísticos em propriedade plural "Quid est?" Almedina, Lisboa, 2014

[3] DG Enterprise \& Industry, European Tourism Indicator System. Toolkit for sustainable destinations, European Union, Bruxelles, 2013 (on line)

[4] Greenpeace, Costa 2012, Informe sobre la situación económica y ambiental del litoral, Greenpeace España, Madrid (http://www.greenpeace.org/espana/) 